\title{
Repair of Cerebrospinal Fluid Leak After Functional Endoscopy Sinus Surgery
}

\author{
Mohamad I Sapta*, Teresa L Wargasetia** \\ *Ear, Nose and Throat - Head and Neck Department, Faculty of Medicine \\ Universitas Kristen Maranatha - Immanuel Hospital Jl. Kopo 161 Bandung 40234 \\ ** Biology Department Faculty of Medicine Maranatha Christian University \\ Jalan Prof. drg. Suria Sumantri MPH No. 65 Bandung 40164 Indonesia \\ Email: indsent27@yahoo.com
}

\begin{abstract}
Cerebrospinal fluid (CSF) leak is one of Functional Endoscopic Sinus Surgery (FESS) complications. Since 2001, it was reported that there is one case of CSF leak as FESS complication in ENT-HN Department, Faculty of Medicine, Maranatha Christian University Immanuel Hospital in Bandung. The purpose of this case report is present clinical findings and management of CSF leak as FESS complication. A-45 year old male with headache as chief complain after undergone FESS five days before. There was a clear rhinorrhea running from patient's right nose. In nasoendoscopic examination, it was showed there was a defect in lamina cribrosa. The result of paranasal sinus computed tomography scanning showed an air column in brain ventricular system. The defect in lamina cribrosa was repaired by transnasal endoscopic using materials such as surgicel, cartilages, and fat tissues. The conclusion is we roll out one case about repair of CSF leak as a FESS complication and it was done with a good result.
\end{abstract}

Keywords: cerebrospinal fluid leak, functional endoscopic sinus surgery 
Case Report

\title{
Reparasi Kebocoran Cairan Otak Pasca Operasi Bedah Sinus Endoskopi Fungsional
}

\author{
Mohamad I. Sapta*, Teresa L. Wargasetia** \\ *Bagian Ilmu Kesehatan Telinga Hidung Tenggorokan-Kepala Leher \\ Fakultas Kedokteran Universitas Kristen Maranatha-RS. Immanuel \\ Jalan Kopo 161 Bandung 40234 Indonesia \\ ** Bagian Biologi Fakultas Kedokteran Universitas Kristen Maranatha \\ Jalan Prof. drg. Suria Sumantri MPH No. 65 Bandung 40164 Indonesia \\ Email: indsent27@yahoo.com
}

\begin{abstract}
Abstrak
Kebocoran cairan otak merupakan salah satu komplikasi yang dapat terjadi pada operasi Bedah Sinus Endoskopi Fungsional (BSEF). Sejak tahun 2001, dilaporkan satu kasus kebocoran cairan otak akibat komplikasi operasi BSEF di Bagian Ilmu Kesehatan THT-KL, Fakultas Kedokteran Universitas Kristen Maranatha-RS Immanuel Bandung. Laporan kasus ini bertujuan untuk menampilkan gambaran klinik yang terjadi serta penatalaksanaan pasien dengan kebocoran cairan otak akibat komplikasi operasi BSEF. Laki-laki, 45 tahun datang dengan keluhan utama nyeri kepala setelah lima hari sebelumnya menjalani operasi BSEF. Terdapat cairan bening yang menetes dari lubang hidung sebelah kanan. Pada pemeriksaan nasoendoskopi didapatkan defek di lamina kribrosa. Hasil computed tomography scanning sinus paranasalis menunjukkan adanya defek ke sistem ventrikel berupa kolom udara. Dilakukan reparasi defek lamina kribrosa per-endoskopi trans-nasal dengan menggunakan surgicel, tulang rawan, dan jaringan lemak. Simpulan adalah telah dilaporkan satu kasus kebocoran cairan otak akibat komplikasi operasi BSEF dan telah dilakukan reparasi defek dengan hasil baik.
\end{abstract}

Kata kunci: kebocoran cairan otak, bedah sinus endoskopi fungsional 
Case Report

\section{Pendahuluan}

Sinusitis adalah peradangan pada sinus paranasal yang dapat disebabkan oleh alergi, infeksi dan trauma. ${ }^{1}$ Peradangan sinus paranasal akibat alergi ditandai dengan infiltrasi sel eosinofil dalam jumlah banyak ke dalam epitel mukosa sinus dan deskuamasi epitelnya. Terjadi proses degranulasi sel mast di submukosa dan jaringan submukosa diinfiltrasi oleh eosinofil, limfosit, dan makrofag. Gangguan pada epitel sinus ini merupakan faktor penting terjadinya infeksi yang berulang pada penderita rhinitis alergi dan sinusitis yang berulang. ${ }^{1,2}$

Infeksi dapat disebabkan oleh virus, bakteri, atau jamur. Infeksi saluran napas atas yang disebabkan oleh virus dapat mengakibatkan peradangan pada sinus dan merupakan faktor predisposisi terjadinya sinusitis yang disebabkan oleh bakteri. Sangatlah sulit untuk membedakan antara sinusitis akut karena virus dan bakteri secara klinis. Adanya kemungkinan sinusitis disebabkan oleh infeksi jamur perlu dipertimbangkan, terutama pada sinusitis kronis yang tidak responsif terhadap terapi medika mentosa. ${ }^{2}$

Gejala sinusitis akut dapat berupa sakit kepala, rasa nyeri di daerah sinus yang terlibat, tanda peradangan periorbita pada anak-anak, rasa tersumbat hidung, post nasal drip, suara serak, batuk, dan sekret purulen. Pada sinusitis kronis, jarang ditemukan gejala lokal di sinus tetapi sering didapatkan post nasal drip dan gejala iritasi orofaring dan laring. Evaluasi sinusitis dapat dilakukan dengan pemeriksaan $x$-ray, tetapi sering terjadi interprestasi yang false negative dan false positive. Computed Tomography Scanning (CT Scan) sinus paranasal memberikan informasi yang sangat sensitif dan spesifik dalam memperlihatkan penebalan mukosa, air fluid level, atau opasitas sinus. Magnetic resonance imaging juga dapat memberikan evaluasi tentang sinus dengan baik. ${ }^{2,3}$

Pengelolaan sinusitis bakterialis meliputi pengobatan antimikroba, drainase sinus (dekongestan intranasal, ipratropium bromide intranasal, irigasi salin intranasal, inhalasi uap hangat, agen ekspektoran dan mukolitik), koreksi terhadap faktor predisposisi, dan pembedahan. ${ }^{1}$

Bakteri yang sering menyebabkan sinusitis adalah bakteri yang menghasilkan beta laktamase dan tidak ada panduan yang pasti untuk menentukan obat yang paling tepat. Obat antimikroba untuk penanganan sinusitis paranasal ditampilkan pada tabel di bawah ini.

\section{Tabel Obat-obatan Antimikroba untuk Sinusitis Paranasal ${ }^{1}$}

\begin{tabular}{ll}
\hline Agen-agen Efektif & Jadwal Pemberian \\
\hline Amoxicillin & $40 \mathrm{mg} / \mathrm{kg} / \mathrm{hari}$ dengan dosis dibagi 3 \\
Amoxicillin-clavulanat & $40 \mathrm{mg} / \mathrm{kg} / \mathrm{hari}$ dengan dosis dibagi 3 \\
Cefaclor & $40 \mathrm{mg} / \mathrm{kg} / \mathrm{hari}$ dengan dosis dibagi 3 \\
Erythromycin-sulfixazole & $50-150 \mathrm{mg} / \mathrm{hari}$ dengan dosis dibagi 4 \\
Trimethoprim-sulfamethoxazole & $320-1600 \mathrm{mg} / \mathrm{hari}$ dengan dosis dibagi 2 \\
\hline
\end{tabular}


Case Report

Sinusitis bakterialis akut, kronis, dan rekuren merupakan komplikasi rinitis alergi. Pembedahan kadang dibutuhkan dalam pencegahan rekurensi sinusitis. Pada pasien dengan rinitis alergi sebagai penyakit yang mendasari terjadinya sinusitis, terapi terhadap rinitis alerginya harus dilakukan lebih agresif untuk mencegah kekambuhan. Pembedahan juga dibutuhkan apabila terapi obat maksimal tidak dapat mengatasi gejala sinusitis paranasal kronis. Bedah Sinus Endoskopi Fungsional (BSEF) merupakan tindakan pilihan dalam penanganan polip hidung atau sinusitis. ${ }^{3,4}$ BSEF saat ini dianggap efektif dan aman bagi anak, dengan tingkat kesuksesan $88 \%$ menurut hasil meta analisis dan tingkat komplikasinya rendah. ${ }^{4}$

BSEF merupakan teknik untuk mengatasi penyakit inflamasi sinus maksila dan frontal, juga etmoid anterior dengan pembedahan faktor-faktor inflamasi atau anatomis yang mengganggu pada unit ostiomeatal dan di saat yang sama mempertahankan mukosa marginal dan mencegah intervensi radikal. ${ }^{5}$ Pendekatan tersebut secara signifikan menyebabkan perbaikan pada obstruksi nasal (91\%), rhinorrhoea (90\%), sakit kepala (97\%), hiposmia (89\%), dan batuk kronis $(96 \%){ }^{6}$

\section{Ilustrasi Kasus}

Dilaporkan satu kasus seorang penderita laki-laki usia 45 tahun, datang ke Instalasi Gawat Darurat RS Immanuel Bandung dengan keluhan nyeri kepala yang dirasakan pada seluruh bagian kepala disertai keluarnya cairan bening dari lubang hidung kanan. Dari hasil anamnesis, didapatkan bahwa lima hari sebelum keluhan dirasakan, penderita telah menjalani operasi bedah sinus endoskopi fungsional di RS Immanuel Bandung. Nyeri kepala mulai dirasakan satu hari setelah penderita diperbolehkan pulang dan didahului keluarnya cairan bening dari lubang hidung sebelah kanan terutama dalam posisi menunduk, tidak disertai kejang atau mual dan muntah. Keluhan nyeri kepala ini dirasakan semakin lama semakin bertambah berat, sehingga penderita dibawa ke Instalasi Gawat Darurat.

Pada pemeriksaan fisik didapatkan keadaan umum tampak sakit sedang, kesadaran kompos mentis, tekanan darah, respirasi, frekuensi nadi dan suhu dalam batas normal. Pada pemeriksaan telinga, mulut, dan tenggorok tidak ditemukan kelainan. Pemeriksaan hidung kanan, pada posisi duduk dengan kepala menunduk didapatkan cairan bening yang menetes, sedangkan hidung kiri tidak ditemukan kelainan, nilai hematologi rutin normal. Penderita didiagnosis dengan observasi kecurigaan nyeri kepala disebabkan oleh kebocoran cairan otak pasca operasi BSEF. Dirawat dengan posisi berbaring terlentang dengan kepala ke atas $30^{\circ}$, diet lunak, dilarang mengedan dan batuk, infus ringer laktat $1.500 \mathrm{cc}$ untuk 24 jam, injeksi seftriakson 1x2 gram (skin test), direncanakan untuk dilakukan eksplorasi dengan 


\section{Case Report}

nasoendoskopi dalam anestesi umum. Segera dilakukan CT scan sinus paranasal tanpa kontras, dengan hasil "ditemukan pneumatokel luas di ventrikel lateral kanan dan frontal kanan".

Pada hari kedua perawatan dilakukan eksplorasi dengan nasoendoskopi dalam anestesi umum dan didapatkan defek di atap etmoid, yaitu di daerah lamina kribrosa kanan dengan ukuran 7x5 mm dengan tepi rata/regular. Dilakukan reparasi defek dengan menggunakan surgicel lalu kartilago yang diambil dari tragus aurikula kanan kemudian jaringan lemak yang diambil dari dinding abdomen. Dipasang tampon pita hidung yang terbuat dari kain kasa dan dilumuri krim garamisin. Kemudian dipasang pipa lumbal untuk mengeluarkan cairan serebro spinal. Diberikan medikasi parenteral (antibiotik dan lain-lain), manitol 20\% setiap 8 jam, aspirasi cairan serebro spinal lewat selang lumbal 3x30 cc/24 jam untuk mencegah tekanan intra kranial meningkat. Tampon hidung dipertahankan selama empat hari, kemudian dilakukan CT scan sinus paranasal pasca pembedahan.

Hasil CT Scan sinus paranasal pra BSEF, pasca BSEF, dan pasca reparasi ditampilkan pada gambar 1,2, dan 3 .

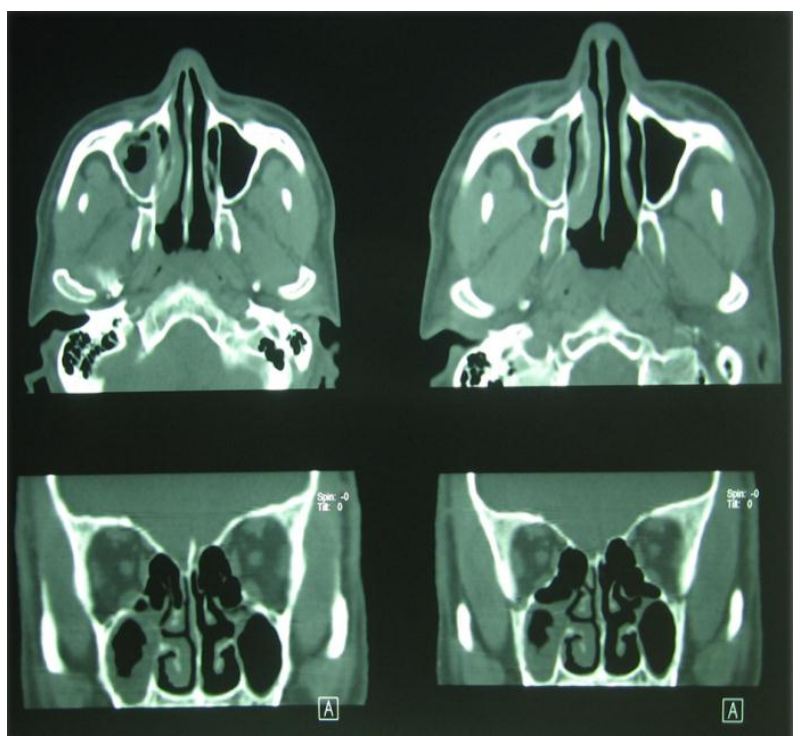

\section{Gambar 1 Hasil CT Scan Sinus Paranasalis Pra BSEF}

Ket: Tampak perselubungan isodens yang mengobliterasi sebagian sinus maksilaris kanan.

Tampak pembesaran konka media kanan dan septum nasi deviasi minimal ke kiri.

Sinus paranasal lainnya tampak cerah.

Kesan: sinusitis maksilaris kanan. Hipertrofi konka kanan. Septum nasi deviasi ke kiri. 


\section{Case Report}

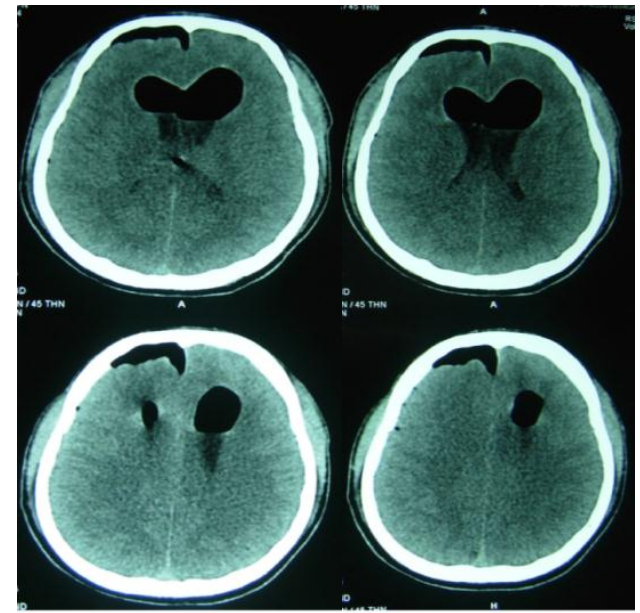

\section{Gambar 2 Hasil CT Scan Sinus Paranasalis Pasca BSEF}

Ket: Tampak defek pada atap sinus etmoidalis posterior kanan dengan terdapatnya udara intrakranial pada bagian subkalvaris frontalis kanan dan ventrikel lateralis kanan kiri terutama kiri serta temporal kanan kiri bagian anterior serta oksipital (minimal). Kesan: pneumatokel multipel intrakranial etcausa defek di atas sinus etmoidalis posterior.

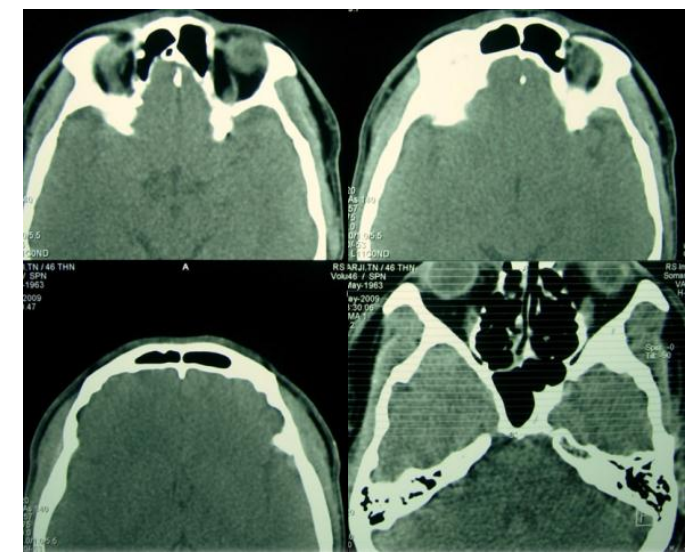

Gambar 3 Hasil CT Scan Sinus Paranasalis pada Hari ke-18 Pasca Reparasi BSEF

Ket: Tidak tampak lagi udara/pneumatokel intrakranial

Reparasi pada defek baik

Kesan: tidak tampak lagi pneumatokel intrakranial

\section{Diskusi}

Telah dilaporkan satu kasus seorang penderita laki-laki usia 45 tahun yang didiagnosis dengan sefalgia et kausa kebocoran cairan otak pasca Bedah Sinus Endoskopi Fungsional (BSEF).

Pengelolaan sinusitis berdasarkan pada tiga prinsip, yaitu terapi antibakteri, drainase sinus dan memperbaiki faktor predisposisi. ${ }^{7}$ Saat ini BSEF adalah gold standard untuk terapi pembedahan untuk sinusitis kronis. BSEF perlu disesuaikan dengan anatomi pasien secara individual dan tidak distandarisasi dengan ketat. 


\section{Case Report}

Pemahaman anatomi hidung dan sinus paranasal merupakan hal yang paling penting dikuasai oleh para ahli bedah untuk menghindari kemungkinan terjadinya komplikasi operasi dengan menggunakan endoskopi. Letak anatomi sinus paranasal yang berdekatan dengan basis kepala sangat berisiko minimbulkan cedera jaringan pembatas pada tindakan endoskopi sinus. Komplikasi intrakranial dapat dibagi menjadi komplikasi selama operasi dan komplikasi pasca operasi. ${ }^{3}$ Komplikasi yang dapat terjadi mulai dari komplikasi minor yang dapat ditangani selama operasi, komplikasi mayor yang dapat dikontrol selama operasi atau operasi perbaikan tanpa bahaya yang permanen, dan komplikasi serius berisiko tinggi akan bahaya yang permanen. ${ }^{8}$ Komplikasi selama operasi meliputi kebocoran cairan otak, perdarahan intrakranial, cedera pada arteri karotis interna/sinus kavernosus, sedangkan komplikasi pasca operasi meliputi pneumoensefalus, meningitis, abses epidural, subdural dan otak. ${ }^{3}$ Walaupun BSEF merupakan cara yang relatif aman dalam memperbaiki drainase sinus, namun kemungkinan terjadinya komplikasi berat adalah $0,5-1 \%$ dan komplikasi ringan sebesar 5-7\%. ${ }^{5}$

Pemeriksaan CT scan sangat disarankan dilakukan sebelum operasi dikerjakan untuk menjadi panduan tindakan yang dikerjakan dengan menggunakan endoskopi dan mencegah kemungkinan terjadinya komplikasi. ${ }^{1}$ Peralatan yang memadai, juga merupakan hal penting untuk menghindari trauma jaringan yang tidak perlu, perdarahan dan meningkatnya resiko komplikasi. ${ }^{3}$

Kebocoran cairan otak yang terdiagnosis selama operasi, harus segera dilakukan reparasi. ${ }^{2,3}$ Cedera yang masih baru terjadi, tandur duramater dapat menggunakan lemak atau otot. Bila tidak terdiagnosis selama operasi, penanganannya seperti pada kebocoran otak spontan, posisi berbaring setengah duduk, tidak mengedan, dan jangan meniup dengan hidung (melakukan valsava). Penanganan dengan operasi diperlukan bila kebocoran menjadi permanen atau berulang, meluasnya kejadian pneumoensefalus atau timbul tanda meningitis., ${ }^{2,3}$

Pada kasus ini, penderita telah menjalani operasi BSEF di RS Immanuel Bandung. Setelah dilakukan tindakan BESF, dua hari kemudian penderita diperbolehkan pulang. Namun satu hari setelah pulang, penderita mengeluh nyeri kepala yang terus dirasakan bertambah berat sehingga penderita dibawa ke IGD RS Immanuel Bandung. Pada penderita ini komplikasi kebocoran cairan otak tidak terdiagnosis selama tindakan berlangsung, sehingga belum dilakukan penanganan awal secara konservatif dengan menempatkan penderita dalam posisi terlentang, melarang penderita mengedan, pemberian antibiotik dan analgetik. Menurut Kaluskar, penanganan penderita dengan kebocoran cairan otak adalah menempatkan penderita dalam posisi terlentang, memasang selang lumbal, dan pemberian manitol selama tiga hari. ${ }^{3}$

Pada penderita ini segera dilakukan pemeriksaan CT Scan dan didapatkan kesan adanya pneumatokel luas di ventrikel lateral kanan dan frontal kanan dan diputuskan untuk melakukan 


\section{Case Report}

eksplorasi keesokan harinya. Pemeriksaan CT Scan dan MRI cisternography merupakan pemeriksaan yang sangat berguna untuk menentukan lokasi kebocoran cairan otak. ${ }^{2,3}$ Penentuan lokasi persisnya kebocoran otak cukup sulit, lokasi yang mungkin adalah anterior, tengah, dan posterior fossa. Cairan serebrospinal cukup sering mencapai nasal cavity melalui sinus frontal, lamina kribrosa, atap spenoid atau tulang petrous melalui telinga tengah dan Eustachian tube. ${ }^{9}$

Ditemukannya defek di atap sinus etmoid atau daerah lamina kribrosa, merupakan tempat di sebelah medial konka media, menandakan bahwa kemungkinan besar disebabkan oleh tindakan BSEF sebelumnya. Fovea ethmoidalis menonjol di daerah ini sehingga trauma ringan saja memudahkan terjadinya kebocoran cairan otak. ${ }^{3,10}$

Pasien ini didiagnosis kerja sebagai kebocoran cairan otak akibat operasi BSEF. Pada pasien ini dilakukan reparasi defek dengan anestesi umum secara endonasal dengan endoskopi. Dilakukan reparasi robekan dengan menggunakan surgicel, kartilago, dan lemak. Bahan lain juga dapat digunakan seperti konka media sebagai free atau pedicle graft, fasia temporalis, otot, dan fasia lata. Perlu disadari bahwa yang penting bukan bahan yang dipergunakan, akan tetapi bagaimana penatalaksanaannya, yaitu teknik reparasi yang benar merupakan hal penting dalam keberhasilan menutup kebocoran., ${ }^{2,3}$ Pada kasus sefalgia et kausa kebocoran cairan otak pasca Bedah Sinus Endoskopi Fungsional ini, telah dilakukan reparasi defek dengan hasil baik.

\section{Daftar Pustaka}

1. Rice DH, Schaefer SD. Endoscopic paranasal sinus surgery $3^{\text {rd }}$ ed. Philadelphia: Lippincott Williams \& Wilkins; 2004.

2. Soler ZM, Smith TL. Results of medical and surgical treatment of chronic rhinosinusitis with and without nasal polyps. In: Flint PW, Haughey BH, Lund VJ, Niparko JK. Robbins KT, Thomas JR et al. Cummings otolaryngology: head \& neck surgery 6th ed. Philadelphia: Elsevier Saunders; 2015:702-13.

3. Kaluskar SK, Sachdeva S. Complication in endoscopic sinus surgery $1^{\text {st }}$ ed. Jaypee brothers MP, Lippincott Williams \& Wilkins; 2002.

4. Stenner M, Rudack C. Diseases of the nose and paranasal sinuses in child. GMS Curr Top Otorhinolaryngol - Head Neck Surg. 2014;13:1-27.

5. Weber RK, Hosemann W. Comprehensive review on endonasal endoscopic sinus surgery. GMS Curr Top Otorhinolaryngol - Head Neck Surg. 2015;14:1-108.

6. Fokkens W, Lund V, Mullol J, Bachert C, Alobid I, Baroody F et al. European position paper on rhinosinusitis and nasal polyps. Rhinol. 2012:50 (Suppl 23).

7. Meltzer EO, Hamilos DL. Rhinosinusitis diagnosis and management for the clinician: a synopsis of recent consensus guidelines. Mayo Clin Proc. 2011;86(5):427-43.

8. Hosemann W, Draf C. Danger points, complications and medico-legal aspects in endoscopic sinus surgery. GMS Curr Top Otorhinolaryngol - Head Neck Surg. 2013;12:1-61.

9. Sharma DP, Singh D, Sinha S, Srivastva AK, Singh H, Jagetia A et al. CSF rhinorrhea: an overview of endoscopic repair. Indian J Neurotrauma. 2010;7(2):157-62.

10. Williams PL. Gray's Anatomy: the anatomical basis of clinical practice 40th ed. London: Churchill Livingstone; 2008. 